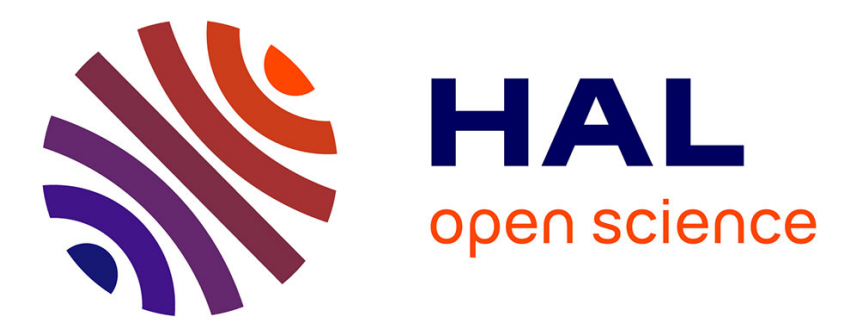

\title{
Jahn-Teller phase transition in Cu0.50TiO(PO4): powder structural characterization of the b-variety and thermal study
}

Pierre Gravereau, Saïd Benmokhtar, Jean-Pierre Chaminade, Abdelaziz El Jazouli, Eric Lebraud, Dominique Denux

\section{To cite this version:}

Pierre Gravereau, Saïd Benmokhtar, Jean-Pierre Chaminade, Abdelaziz El Jazouli, Eric Lebraud, et al.. Jahn-Teller phase transition in $\mathrm{Cu} 0.50 \mathrm{TiO}(\mathrm{PO} 4)$ : powder structural characterization of the b-variety and thermal study. Solid State Sciences, 2007, 9 (3-4), pp.258-266. 10.1016/j.solidstatesciences.2007.02.004 . hal-00144736

\section{HAL Id: hal-00144736 \\ https://hal.science/hal-00144736}

Submitted on 4 May 2007

HAL is a multi-disciplinary open access archive for the deposit and dissemination of scientific research documents, whether they are published or not. The documents may come from teaching and research institutions in France or abroad, or from public or private research centers.
L'archive ouverte pluridisciplinaire HAL, est destinée au dépôt et à la diffusion de documents scientifiques de niveau recherche, publiés ou non, émanant des établissements d'enseignement et de recherche français ou étrangers, des laboratoires publics ou privés. 


\title{
Jahn Teller phase transition in $\mathrm{Cu}_{0.50} \mathrm{TiO}\left(\mathrm{PO}_{4}\right)$ : powder structural characterization of the $\beta$-variety and thermal study.
}

\author{
Pierre Gravereau $^{\mathrm{a} *}$, Saïd Benmokhtar ${ }^{\mathrm{b}}$, Jean-Pierre Chaminade ${ }^{\mathrm{a}}$, \\ Abdelaziz El Jazouli ${ }^{\mathrm{b}}$, Eric Lebraud ${ }^{\mathrm{a}}$, Dominique Denux ${ }^{\mathrm{a}}$ \\ ${ }^{a}$ Institut de Chimie de la Matière Condensée de Bordeaux [ICMCB-CNRS, UPR 9048], \\ Université de Bordeaux 1, 87 Av. Dr. Schweitzer, 33608 Pessac France. \\ ${ }^{\mathrm{b}}$ Laboratoire de Chimie des Matériaux Solides, Faculté des Sciences Ben M'Sik, \\ Casablanca, Maroc
}

\begin{abstract}

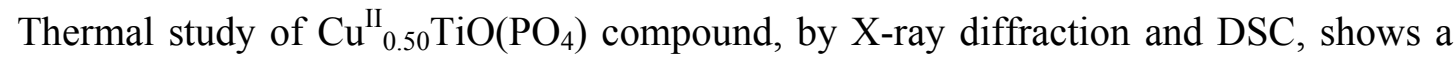
phase transition $\alpha \rightarrow \beta$ with hysteresis $\left(\sim 600^{\circ} \mathrm{C}\right.$ during heating; $\sim 300^{\circ} \mathrm{C}$ during cooling). Therefore single crystals have been obtained for the $\alpha$-phase, the $\beta$-phase can only be stabilised at room temperature in a powder mixture $(\alpha+\beta)$. Structural characterization of the $\beta$-variety has been done with diffraction data (X-ray $\mathrm{Cu}-\mathrm{K} \alpha_{1}$ and neutrons) of the richer powder in $\beta$-phase $(\alpha(20 \%)+\beta(80 \%)$. From the X-ray data, a P2 $1 / \mathrm{c}$ monoclinic cell $(\mathrm{a}=7.1134(7) \AA ; \mathrm{b}=7.7282(7) \AA ;$ $c=7.3028(7) \AA ; \beta=119.30(1)^{\circ} ; \mathrm{V}=350.1(1) \AA^{3}$ ) has been found for $\beta$-phase. An "ab-initio" structure determination has been done, and Rietveld refinement leads to $\mathrm{cR}_{\mathrm{wp}}=0.150$ and $\mathrm{R}_{\mathrm{B}}=0.041$. Results are confirmed by refinements from neutrons data.
\end{abstract}

As for the $\alpha$-phase the structure of $\beta-\mathrm{Cu}_{0.50}{ }^{\mathrm{II}} \mathrm{TiO}\left(\mathrm{PO}_{4}\right)$ can be described as a $\mathrm{TiOPO}_{4}$ framework constituted by chains of tilted corner-sharing $\left[\mathrm{TiO}_{6}\right]$ octahedra running parallel to the c axis and cross linked by $\left[\mathrm{PO}_{4}\right]$ tetrahedra. Ti atoms are displaced from the center of the octahedra 
units in alternating long $\left(2.27 \AA ̊\right.$ ) and short $\left(1.73 \AA\right.$ Á) Ti-O(1) bonds. The $\left[\mathrm{CuO}_{6}\right]$ octahedra exhibit typical Jahn Teller distorted coordination with four short equatorial $\mathrm{Cu}-\mathrm{O}$ bonds $(2 \times 1.93 \AA$ and $2 \times 2.06 \AA$ ), and two longer apical $\mathrm{Cu}-\mathrm{O}$ bonds $(2 \times 2.33 \AA$ ). The two longer $\mathrm{Cu}-\mathrm{O}$ bonds are almost parallel to $\mathbf{b}$ axis.

So, the transition from $\alpha$ to $\beta$ phasis is characterized by a "rocking" of the Jahn Teller elongation from the (a,c) plane to the $\mathbf{b}$ direction accompanied by a relatively strong expansion of cell volume.

Keywords : Copper titanium oxyphosphate, Jahn Teller phase transition, powder diffraction , $a b$ initio structure determination.

* Correspondence and reprints : Fax +33 (0)5 40002761

e-mail graver@icmcb-bordeaux.cnrs.fr

\section{Graphical Abstract : Figure 7}




\section{Introduction}

The research on phosphate materials is currently in progress due to their exceptional optical and laser properties. Since the discovery of exceptional nonlinear optical and electrooptical properties in $\mathrm{KTiO}\left(\mathrm{PO}_{4}\right)$ [1], great number of oxyphosphates have been investigated. Our original research interest is focused on titanium phosphates with the formula $\mathrm{M}_{0.50}^{\mathrm{II}} \mathrm{TiO}\left(\mathrm{PO}_{4}\right)$. We have recently reported a new structural type in these families with the powder "ab initio" structure determination of $\mathrm{Ni}_{0.5} \mathrm{TiO}\left(\mathrm{PO}_{4}\right)$ [2]. Study of $\mathrm{Cu}_{0.50} \mathrm{TiO}\left(\mathrm{PO}_{4}\right)$ compound shows a phase transition with temperature, reversible but with hysteresis. The $\alpha$-room temperature phase has been characterized : single crystal structure determination with a Jahn Teller deformation of Cuenvironment, and optical study [3]. The present paper reports with structural powder study (X-ray and neutrons) of the $\beta$-high temperature phase and with the $\alpha \rightarrow \beta$ transition.

\section{Experimental section}

\subsection{Powders synthesis}

The new oxyphosphate $\mathrm{Cu}_{0.50} \mathrm{TiO}\left(\mathrm{PO}_{4}\right)$ can be synthesized either from solids (i) or solutions (ii) as starting products :

(i) stoichiometric mixture of $\mathrm{CuO}, \mathrm{TiO}_{2}$ and $\left(\mathrm{NH}_{4}\right) \mathrm{H}_{2} \mathrm{PO}_{4}$ according to the reaction :

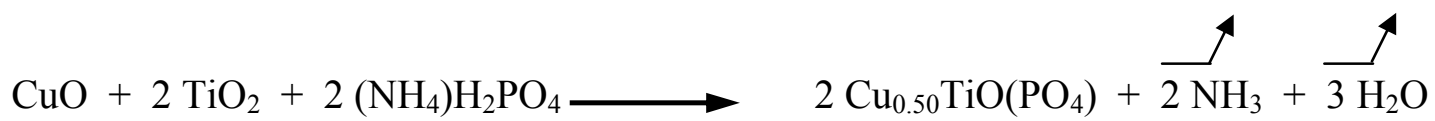

The initial mixture was preheated at $250^{\circ} \mathrm{C}(18 \mathrm{hr})$, followed by several thermal treatments from $200^{\circ} \mathrm{C}$ to $950^{\circ} \mathrm{C}(24 \mathrm{hr})$. The final product is light blue.

(ii) aqueous solutions of $\mathrm{Cu}\left(\mathrm{NO}_{3}\right)_{2}, 3 \mathrm{H}_{2} \mathrm{O}$ (I), $\left(\mathrm{NH}_{4}\right) \mathrm{H}_{2} \mathrm{PO}_{4}$ (II) and diluted $\mathrm{TiCl}_{4}$ in ethanol (III) in stoichiometric proportions. After a slow addition of (III) to (I + II) at room temperature, the 
mixture (precipitate + solution) is heated at $70^{\circ} \mathrm{C}$ in order to remove liquid. The powder obtained was then heated progressively with intermittent regrinding from $250^{\circ} \mathrm{C}$ to $950^{\circ} \mathrm{C}$. The final product is also light blue. Above $1000^{\circ} \mathrm{C}$ (depending of $\mathrm{O}_{2}$ partial pressure) there is a decomposition leading to $\mathrm{CuTi}_{2}\left(\mathrm{PO}_{4}\right)_{3}$ (Nasicon type), $\mathrm{TiO}_{2}$ (rutile type) and $\mathrm{Cu}_{2} \mathrm{O}$.

Depending of the temperature treatments, the two synthesis ways (from solids or solutions) can lead to powders with different X-ray patterns. In a first time it was not possible to refine a good monoclinic cell of Ni-type [2]. Thermal studies of several of these powders gave us explanation for the different results : this compound presents two allotropic phases named $\alpha$ and $\beta$, and generally the different synthesis lead to $(\alpha+\beta)$ mixture. In some particular conditions we succeed to obtain the $\alpha$-phase alone.

From these powders some tries have been done to obtain single crystals. Some annealings under $\mathrm{O}_{2}$ flow near decomposition temperature $\left(1000^{\circ} \mathrm{C}\right)$, followed by slow cooling, lead to the formation of $\alpha$-single crystals $(<100 \mu \mathrm{m})$ which were used for structure determination [3]. But we never succeeded for suitable $\beta$-single crystals.

So structure determination of the $\beta$-phase was undertaken with $(\alpha+\beta)$-powder diffraction data. For this we have selected among our preparations the room temperature mixture richer in $\beta$ phase $\left(\approx 20 \%\right.$ for $\alpha$ and $\approx 80 \%$ for $\beta$ in weight fractions). This powder is named $\left(\alpha_{20}+\beta_{80}\right)$-powder in the following. Idea is to search structural model with high temperature X-ray diffraction data with $\beta$-phase alone, and then to refine it with $\left(\alpha_{20}+\beta_{80}\right)$-powder room temperature data which, in spite of the mixture, are of better quality.

\subsection{Diffraction data}

- room temperature diffraction data with $\left(\alpha_{20}+\beta_{80}\right)$-powder : 


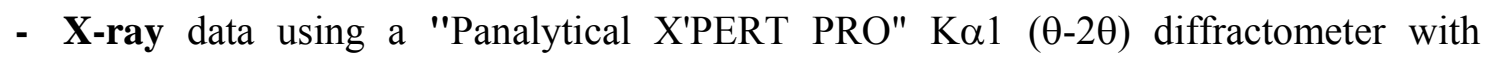
subsequent experimental conditions : Bragg-Brentano geometry ; CuKa1 radiation (45 $\mathrm{kV}, 40 \mathrm{~mA}$ ) ; incident-beam with germanium (111) monochromator, Soller slits of 0.02 rad, antiscatter slit of $1 / 2^{\circ}$; diffracted-beam with antiscatter slit of $5 \mathrm{~mm}$, Soller slits of $0.02 \mathrm{rad}, \mathrm{X}^{\prime}$ Celerator detector ; holder surface dusted with $20 \mu \mathrm{m}$ sieve and corrected with a razor blade ; sample spinner used; steps of $0.008^{\circ}(2 \theta)$ over the angular range $10-120^{\circ}(2 \theta)$ with a total counting time of $16 \mathrm{~h} 35 \mathrm{mn}$.

- Neutrons data collected at the LLB-Orphée reactor (CEA/Saclay, France), on the 3T2 high resolution powder diffractometer : focusing (335) Ge monochromator ; $\lambda=122.51 \mathrm{pm}$; steps of $0.05^{\circ}(2 \theta)$ over the angular range $6^{\circ}-125.70^{\circ}(2 \theta) ; 20 \mathrm{He}^{3}$ detectors.*.

*acknowledgements to F. Bourée (LLB-CEA/Saclay/France) for room temperature neutrons data.

\section{- high temperature X-ray diffraction data :}

Collected data using "Panalytical X'PERT MPD" $(\theta-\theta)$ with HTK16 Anton Paar camera:

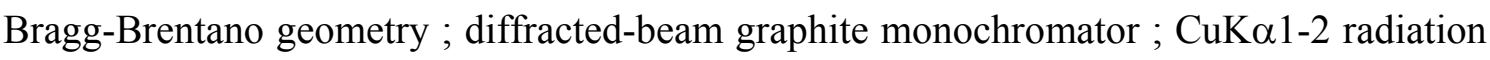
$(40 \mathrm{kV}, 50 \mathrm{~mA})$; Soller slits of $0.04 \mathrm{rad}$ on incident and diffracted beams ; divergence slit of $1^{\circ}$; antiscatter slit of $1^{\circ}$; receiving slit of $0.1 \mathrm{~mm}$; platinum heating filament surface dusted with $20 \mu \mathrm{m}$ sieve and corrected with a razor blade. The HTK16 camera is equipped with two thermocouples Pt-Pt/Rh. The first one ( control thermocouple ) is welded under the heating filament and the other one ( reference thermocouple ) is placed as close as possible to the surface of the sample. With this kind of device, the most significant sources of possible errors are: gradient within the sample holder, contact between the sample and 
the sample holder and gradient within the sample itself. Moreover, the difference between control and reference thermocouple is increasing with temperature.

Two studies have been done : one with powder obtained by crushed single crystals of the $\alpha$-phase (named $\alpha_{100}$-powder in the following) (Fig. 1a), and the other with $\left(\alpha_{20}+\beta_{80}\right)$ powder (Fig. 1b). Collects are done by heating $(25,100,200,300,400,500,600,700$, $\left.800,900{ }^{\circ} \mathrm{C}\right)$ and then by cooling to room temperature $(800,700,600,500,400,300$, $\left.200,100,25^{\circ} \mathrm{C}\right)$ with the following conditions : angular range $10-80^{\circ}(2 \theta)$; steps of $0.02^{\circ}(2 \theta)$; counting time of $5 \mathrm{~s}$ by step ; slope of $2^{\circ} \mathrm{C} \cdot \mathrm{mn}^{-1}$ and a holding time of $30 \mathrm{mn}$ for each level. Patterns evolution (Fig. 1) shows phase-transition with hysteresis $(\mathrm{T}(\alpha \rightarrow \beta)>\mathrm{T}(\beta \rightarrow \alpha))$, but the transition temperatures appear slightly different depending on the starting powder composition.

\subsection{Thermal study with the room temperature $\alpha_{100}$-powder}

\section{- calorimetry:}

Calorimetry has been performed on a power compensation calorimeter Perkin Elmer DSC7. Two experiments have been necessary to obtain after calculation the results presented above. To keep a good sensitivity we have choosen to work with a slope of $3^{\circ} \mathrm{C} / \mathrm{min}$.

\section{- dilatometry:}

To measure the temperature dependant change in length $\Delta \mathrm{L}$ of the $\alpha_{100}$-powder, we have used a Netzsch differential dilatometer that allows the direct measurement of the difference in deformation between a specimen and a reference sapphire body using a displacement transducer. This measurement is corrected from the reference material expansion 
coefficient. A pastille have been made from the $\alpha_{100}$-powder with a compaction pressure of $500 \mathrm{Mpa}$.

\section{Structure determination of $\beta-\mathrm{Cu} 0.50 \mathrm{TiO}\left(\mathrm{PO}_{4}\right)$ phase}

\subsection{First approach with $500^{\circ} \mathrm{C} \downarrow$ pattern of $\left(\alpha_{20}+\beta_{80}\right)$-powder}

A preliminary study has been done using $\left(\alpha_{20}+\beta_{80}\right)$-powder pattern recorded at $500^{\circ} \mathrm{C}$ in the cooling cycle part from $900^{\circ} \mathrm{C}$ to room temperature $(\Rightarrow \beta$ alone $)$ : angular range $10^{\circ}-120^{\circ}(2 \theta)$; steps of $0.02^{\circ}(2 \theta) ; 30$ s counting time by step.

\section{- indexing and cell refinement of $\beta\left(500^{\circ} \mathrm{C} \downarrow\right)$ pattern}

Use of DICVOL program [4] leads to a good monoclinic cell which is compatible with $\mathrm{P} 2{ }_{1} / \mathrm{c}$ space group : $\mathrm{a}=7.135 \AA, \mathrm{b}=7.723 \AA, \mathrm{c}=7.321 \AA, \beta=119.37^{\circ}(\mathrm{M}(24) \approx 45)$. These cell and space group are confirmed with the "profile matching" option of FULLPROF program [5] : $\mathrm{R}_{\mathrm{wp}}=0.035 ; \mathrm{c}_{\mathrm{wp}}=0.152 ; \chi^{2}=3.60$. We can notice that this new cell corresponds to an important evolution of the $\alpha$-cell $(a=7.5612(4) \AA, b=7.0919(4) \AA, c=7.4874(4) \AA$, $\beta=122^{\circ} .25$ ), particularly with the great increase of the $\mathbf{b}$ parameter.

\section{- structure determination of $\beta\left(500^{\circ} \mathrm{C} \downarrow\right)$}

In spite of identical space group, Rietveld refinement starting with atomic parameters of the $\alpha$-phase is not possible. High values of the agreement factors and divergence of the refinement confirms a too important structure modification. So we have undertaken a $a b$ initio structure determination with a starting file of 276 structure factors of resolved reflexions selected in the range $10^{\circ}-100^{\circ}(2 \theta)$ because they have no neighbouring reflexion at less than $0.25^{*}$ FWHM (Full Width at Half Maximum). Patterson-function deconvolution with SHELXS97 program [7] leads to $\mathrm{Cu}$ and Ti atoms localisation. Successive difference 
Fourier syntheses using SHELXL97 program [7] and structure factor values improved by Rietveld calculation during structure determination progress, allowed us to locate $\mathrm{P}$ and $\mathrm{O}$ atoms. The obtained structural model was further refined with the full profile Rietveld method on the whole angular range $10-120^{\circ}(2 \theta)$. Quality of the model is attested by good cristallochemistry results and satisfactory profile factors $\left(\mathrm{R}_{\mathrm{wp}}=0.043 ; \mathrm{cR}_{\mathrm{wp}}=0.210\right.$; $\left.R(I)=0.091 ; \chi^{2}=5.10\right)$, but it can be improved with the better room temperature $\left(\alpha_{20}+\beta_{80}\right)$ data .

3.2. Structure refinement of $\beta$-phase with $\left(\alpha_{20}+\beta_{80}\right)$-powder $X$-ray and neutrons room temperature data

For the two kinds of data (X-ray and neutrons), Rietveld refinements have been done in the following way : atomic coordinates of the $\alpha$-phase fixed with single crystal obtained values [3] precedent structure found for $\beta\left(500^{\circ} \mathrm{C} \downarrow\right)$ used as starting model for $\beta$-phase - one averaged thermal parameter by atom type with the same value in $\alpha$ and $\beta$ phases - Pseudo-Voigt profile function with Caglioti law including instrumental parameters. Structural data and Rietveld refinement results are summarized in Table 1. Fig. 2 displays the agreement obtained between observed and calculated profiles. The final atomic parameters are given in Table 2 and selected bond distances and angles in Table 3. Standard deviations have been multiplied by Berar factor [8] to correct local correlations. Valence bond sums (Table 4) based on bond-strength analysis [9-10] are in good agreement with the expected formal oxidation state of $\mathrm{Cu}^{2+}, \mathrm{Ti}^{4+}, \mathrm{P}^{5+}$ and $\mathrm{O}^{2-}$ ions.

\section{Description of the $\beta-\mathrm{Cu} 0.50 \mathrm{TiO}\left(\mathrm{PO}_{4}\right)$ phase structure}


$\alpha$ and $\beta \mathrm{Cu}_{0.50} \mathrm{TiO}\left(\mathrm{PO}_{4}\right)$ structures consist of a three-dimensional (3D) framework built up from $\left[\mathrm{TiO}_{6}\right]$ octahedra and $\left[\mathrm{PO}_{4}\right]$ tetrahedra. The $\left[\mathrm{TiO}_{6}\right]$ octahedra are linked by corners along $\mathrm{c}$ axis while the $\left[\mathrm{PO}_{4}\right]$ tetrahedra are separated from each others. $\mathrm{Cu}$ atoms are inserted in octahedral sites of the framework. The dominant structural units are chains of tilted corner-sharing $\left[\mathrm{TiO}_{6}\right]$ octahedra running parallel to the $\mathbf{c}$ axis (Fig. 3). Two successive $\left[\mathrm{TiO}_{6}\right]$ octahedra of the same chain are connected by $\mathrm{O}(1)$, and share the other four corners $(\mathrm{O}(2), \mathrm{O}(3), \mathrm{O}(4)$ and $\mathrm{O}(5))$ with $\left[\mathrm{PO}_{4}\right]$ tetrahedra (Fig. 4). The $\left[\mathrm{TiO}_{6}\right]$ octahedra are distorted with an alternance of very short $\mathrm{Ti}-\mathrm{O}(1)$ bonds $(\approx 1.72 \AA)$ and a very long one $(\approx 2.30 \AA)$ : the long bond corresponds to $\mathrm{O}(1)$ implied in a common face between $\left[\mathrm{TiO}_{6}\right]$ and $\left[\mathrm{CuO}_{6}\right]$ and the short bond to $\mathrm{O}(1)$ as a common apex between $\left[\mathrm{TiO}_{6}\right]$ and $\left[\mathrm{CuO}_{6}\right]$. One can notice this $\mathrm{O}(1)$ oxygen atom, not linked to $\left(\mathrm{PO}_{4}\right)$ tetrahedra, justifying the oxyphosphate formulation $\mathrm{Cu}_{0.50} \mathrm{TiO}\left(\mathrm{PO}_{4}\right)$.

The $\mathrm{Cu}^{2+}$ ion occupy the symmetry center of an octahedron formed by $2 \mathrm{xO}(1), 2 \mathrm{xO}(2)$ and $2 \mathrm{xO}(5)$ atoms. As a result of Jahn-Teller effect $\left(\mathbf{t}_{2 \mathbf{g}}^{\mathbf{6}} \mathbf{d}_{\mathbf{z}^{2}}{ }^{2} \mathbf{d}_{\mathbf{x}^{2}-\mathbf{y}^{2}}^{\mathbf{1}}\right.$ configuration of $\mathrm{Cu}^{2+}$ ion) we observe a strong distorsion of $\left[\mathrm{CuO}_{6}\right]$ octahedron with 4 short bonds and 2 longer ones. In $\alpha-\mathrm{Cu}_{0.50} \mathrm{TiO}\left(\mathrm{PO}_{4}\right)$ long bonds between $\mathrm{Cu}$ and $\mathrm{O}(2)$ are almost parallel to $(\mathbf{a}, \mathbf{c})$ plane $(\Rightarrow$ increases of $\mathbf{a}$ and $\mathbf{c}$ cell parameters and decrease of the $\mathbf{b}$ one), when in $\beta-\mathrm{Cu}_{0.50} \mathrm{TiO}\left(\mathrm{PO}_{4}\right)$ the long bonds are between $\mathrm{Cu}$ and $\mathrm{O}(5)$, almost parallel to $(\mathbf{b})$ axis $(\Rightarrow$ increases of $\mathbf{b}$ cell parameter and decrease of the $\mathbf{a}$ and $\mathbf{c}$ ones). Table 5 shows evolution of cells in $M_{0.50} \mathrm{TiO}\left(\mathrm{PO}_{4}\right)$ compounds according to $M$ size. It can be observed that all the cell parameters and volumes obtained for $\boldsymbol{M}=\mathrm{Fe}, \mathrm{Co}, \mathrm{Zn}, \mathrm{Mg}, \mathrm{Ni}$, are between the ranges of variations of the corresponding values when going from $\alpha-\mathrm{Cu}$ to $\beta-\mathrm{Cu}$. So phase transition from $\alpha-\mathrm{Cu}_{0.50} \mathrm{TiO}\left(\mathrm{PO}_{4}\right)$ to $\beta-\mathrm{Cu}_{0.50} \mathrm{TiO}\left(\mathrm{PO}_{4}\right)$ appears to be essentially consecutive to a rocking of the Jahn-Teller effect in the octahedral $\mathrm{Cu}$ environment accompanied by a relatively strong expansion of the cell volume. 


\section{Thermal study of the $\mathrm{Cu}_{0.50} \mathrm{TiO}\left(\mathrm{PO}_{4}\right) \alpha \rightarrow \beta$ transition phases}

\subsection{Powders composition evolutions and hysteresis of transition temperatures}

Evolution of the quantitative phase analysis (respective weight fractions of $\alpha$ and $\beta$-phase) with temperature has been obtained from Rietveld refinements with the different X-ray diffraction data. It is a favourable case for the accuracy of results obtained by this method because of the negligible effect of microabsorption of Brindley [11] (the linear absorption coefficients are quite similar for the two phasis).

\section{- X-ray diffraction data and calorimetry with $\left(\alpha_{100}\right)$-powder :}

Fig. 5a shows the evolution of the $\alpha$-phase weight fraction during a thermal cycle, when starting with $\alpha_{100}$-powder. Transition $\alpha \rightarrow \beta$ is observed when increasing temperature in the range $550-650^{\circ} \mathrm{C}$. When cooling from $900^{\circ} \mathrm{C}$ transition $\beta \rightarrow \alpha$ occurs in a bigger range around $350^{\circ} \mathrm{C}$ (from 450 to $150^{\circ} \mathrm{C}$ ). Within e.s.d. these observations are reproductible in consecutive thermal cycles.

They can be compared with results obtained by the calorimetric study (Fig. 6a). When increasing temperature, transition $\alpha \rightarrow \beta$ is observed with an endothermic peak (from $530^{\circ} \mathrm{C}$ to $600^{\circ} \mathrm{C}$, with a maximum at about $565^{\circ} \mathrm{C}$ ). In the cooling part the transition $\beta \rightarrow \alpha$ occurs with an exothermic peak (from $415^{\circ} \mathrm{C}$ to $285^{\circ} \mathrm{C}$, with a maximum at about $380^{\circ} \mathrm{C}$ ).

\section{- X-ray diffraction data with $\left(\alpha_{20}+\beta_{80}\right)$-powder :}

When starting with $\left(\alpha_{20}+\beta_{80}\right)$-powder, the evolution of the $\alpha$-phase weight fraction during a thermal cycle is quite different (Fig. 5b). There is always hysteresis but transitions are observed in a continuous way : $\alpha \rightarrow \beta$ when increasing temperature in the range room temperature $-800^{\circ} \mathrm{C}$ (inflexion point at about $500^{\circ} \mathrm{C}$ ) ; $\beta \rightarrow \alpha$ when cooling appears from 
$300^{\circ} \mathrm{C}$ to room temperature. Within e.s.d. these results are also reproductible in consecutive thermal cycles.

\subsection{Dilatometry with cell expansion during $\alpha \rightarrow \beta$ transition}

Cell volume evolution for $\alpha$ and $\beta$ phases have been obtained from increasing temperature patterns for $\left(\alpha_{20}+\beta_{80}\right)$-powder (Fig. 5c). We can see that, in the range $500-600^{\circ} \mathrm{C}, \alpha \rightarrow \beta$ transition is accompanied by a cell expansion of $\sim 10 \AA^{3}(\Delta \mathrm{V} / \mathrm{V} \sim 3 \%)$.

Fig. $6 \mathrm{~b}$ shows dilatometry result with $\alpha_{100}$-powder. The length expansion temperature range (between $515-560^{\circ} \mathrm{C}$ ) is in good agreement with that of the endothermic calorimetric peak. The same comment is available for cooling with a lengh contraction in the range that corresponds to an exothermic calorimetric peak $(\Delta \mathrm{H} \sim 6 \mathrm{~J} / \mathrm{g} . \mathrm{K})$.

Furthermore complementary experiments of both dilatometry and calorimetry confirm that working rate doesn't modify the temperature of the transition beginning. $\mathrm{A} 110^{\circ} \mathrm{C}$ hysteresis is observed.

On the other hand, the temperature range of the transition $\beta \rightarrow \alpha$ is slightly affected by the cooling rate. Finally, the observed relative dilatation during heating $(\Delta 1 / 1 \sim 4 \%)$ is four times greater than the expected value. This can be explained by the amount of mechanical constraints induced by the phase transition that cause micro-desagregation of the pellet and amplify the change lengh only resulting from the $\alpha \rightarrow \beta$ transition. After constraints relaxation, the cooling stage exhibits a relative contraction closer to the expected value for the transition $\beta \rightarrow \alpha(\Delta \mathrm{l} / 1 \sim 1 \%)$.

\section{Conclusion}

Synthesis of $\mathrm{Cu}_{0.50} \mathrm{TiO}\left(\mathrm{PO}_{4}\right)$ lead to powders which are mixture of the 2 allotropic phases named $\alpha$ and $\beta$. From these powders we never succeeded to obtain suitable $\beta$-single crystals. Thermal study shows $\alpha \leftrightarrow \beta$ transition with hysteresis $\left(\mathrm{T}_{\text {cooling }}<\mathrm{T}_{\text {heating }}\right)$ and with temperature values 
depending of the starting powder composition. Another observation is that, starting with $(\alpha, \beta)$ mixtures of different compositions, after coming back to room temperature at the end of a thermal cycle, the final composition is the same that the initial one (the metastable fraction of $\beta$-phase is conserved).

Structure model of the $\beta$ variety has been found using the single phase high temperature $\mathrm{X}$ ray pattern $\left(500^{\circ} \mathrm{C}\right.$ when cooling). Refinements have been done with $\left(\alpha_{20}+\beta_{80}\right)$-powder (the richer one in $\beta$-phase) and room temperature diffraction data (X-ray and neutrons). In spite of relatively strong difference between their cell parameters, $\alpha$ and $\beta$ varieties have similar structural types in the same space group $\mathrm{P} 2{ }_{1} / \mathrm{c}$. The singular behaviour of $\mathrm{Cu}_{0.50} \mathrm{TiO}\left(\mathrm{PO}_{4}\right)$ compound in $\mathrm{M}_{0.50}^{\mathrm{II}} \mathrm{TiO}\left(\mathrm{PO}_{4}\right)$ serie is due to Jahn-Teller effect in octahedral $\mathrm{Cu}$ environment. The $\alpha \rightarrow \beta$ transition is also related to this effect with an orientation change for the long bonds $\mathrm{Cu}-\mathrm{O}$, accompanied by a cell expansion. Dilatometry shows also this volume variation of the powder during both $\alpha \rightarrow \beta$ and $\beta \rightarrow \alpha$ transitions. Transitions temperatures hysteresis can be attributed to relaxation in this rocking of the Jahn-Teller effect in $\mathrm{Cu}$ octahedra.

\section{Acknowledgements :}

This work was supported by the "Programme International de Coopération Scientifique , PICS , of CNRST/Morocco - CNRS/France". 


\section{REFERENCES}

[1] F.C. Zumsteg, J.D. Bierlein, T.E. Gier, J. Appl. Phys. 47 (1976) 4980.

[2] P. Gravereau, J.P. Chaminade, B. Manoun, S. Krimi, A. El Jazouli, Powder Diffr. 14(1) (1999) 10.

[3] S. Benmokhtar, H. Belmal, A. El Jazouli, J.P. Chaminade, P. Gravereau, S. Pechev, J.C.

Grenier, G. Villeneuve, D. de Wall, J. Solid State Chem. in Press, Accepted Manuscript

[4] A. Boultif, D. Louër, J. Appl. Cryst. 24 (1991) 987.

[5] J. Rodriguez-Carvajal, In Collected Abstract of Powder Diffraction Meeting, Toulouse, France (1990) 127.

[6] H. M. Rietveld, J. Appl. Cryst. 2 (1969) 65.

[7] G.M. Sheldrick, SHELXS-97, SHELXL-97, University of Göttingen, Germany (1997)

[8] J.F. Bérar, P. Lelann, J. Appl. Cryst. J. 24 (1991) 1.

[9] I. D. Brown, D. Altermatt, Acta Cryst. B 41(4) (1985) 244.

[10] N. E. Brese, M. O’Keefe, Acta Cryst. B (1991) 192.

[11] G. W. Brindley, Phil. Mag. 36 (1945) 347. 
Table 1 : Structural data and Rietveld refinement parameters for $\beta-\mathrm{Cu}_{0.50} \mathrm{TiO}\left(\mathrm{PO}_{4}\right)$

(first values for X-ray - second italic values for neutrons ; e.s.d. corrected with "Berar factor"[8] )

Space group

$\mathrm{a}(\AA)$

$\mathrm{b}(\AA)$

$\mathrm{c}(\AA)$

$\beta\left(^{\circ}\right)$

Volume $\left(\AA^{3}\right)$

$\mathrm{d}_{\mathrm{th}}$

$\mathrm{Z}$

Wavelength $(\AA)$

Diffractometer

Step scan increment $\left({ }^{\circ} 2 \theta\right)$

$2 \theta$ range $\left(^{\circ}\right)$

Temperature $(\mathrm{K})$

Program

Zero point $\left({ }^{\circ} 2 \theta\right)$

Analytical function for full width at half-maximum $(\mathrm{H})$ :

$\mathrm{H}^{2}=\left(\mathrm{U}+\mathrm{U}_{0}\right) \operatorname{tg}^{2} \theta+\mathrm{V}_{0} \operatorname{tg} \theta+\mathrm{W}_{0}+\mathrm{IG} / \cos ^{2} \theta$
$\mathrm{P} 2{ }_{1} / \mathrm{c}$

7.1134(7) 7.119(3)

7.7282(7) 7.718(3)

$7.3028(7) \quad 7.303(3)$

$119.30(1) \quad 119.34(4)$

350.1(1) 349.8(3)

3.623 .62

4

$\lambda \mathrm{K} \alpha 1 \mathrm{Cu}=1.54060 \AA$

$\lambda=1.2251 \AA$

X'PERT PRO-K $\alpha 1$ PANALYTICAL

$3 T 2$ (LLB-Saclay-FRANCE)

$0.008 \quad 0.050$

10.000-119.992 6.000-125.700

294300

Fullprof

$0.005(5)-0.013(6)$

$\mathrm{U}_{0}=0.0065 \quad 0.3225$

$\mathrm{U}=0.175(8) \quad 0.66(11)$

$\mathrm{V} 0=0.0000-0.4975$

$\mathrm{W} 0=0.0021 \quad 0.2475$

$\mathrm{IG}=0.0016(3) \quad 0.01(2)$

Pseudo-voigt function:

$$
P V=\eta L+(1-\eta) G
$$

$\eta=0.49(2) \quad 0.45(14)$

No. of reflections

No. of refined parameters

$517 \quad 1087$

$53 \quad 50$

wt $\%$ ( $\alpha$-phase)

wt $\%$ ( $\beta$-phase)

20(1)

$80(1)$

$\mathrm{R}_{\mathrm{F}}$ ( $\alpha$-phase)

$\mathrm{R}_{\mathrm{B}}$ ( $\alpha$-phase)

$\mathrm{R}_{\mathrm{F}}$ ( $\beta$-phase)

$\begin{array}{ll}0.037 & 0.020\end{array}$

$\begin{array}{ll}0.064 & 0.038\end{array}$

$\begin{array}{ll}0.033 & 0.019\end{array}$

$\begin{array}{ll}0.041 & 0.037\end{array}$

$\begin{array}{ll}0.071 & 0.031\end{array}$

$\begin{array}{lll}0.095 & 0.039\end{array}$

$\begin{array}{lll}0.129 & 0.067\end{array}$

$\begin{array}{ll}0.150 & 0.075\end{array}$

$2.70 \quad 3.27$

$\chi^{2}$

* : without background 
Table 2 : Atomic coordinates and isotropic temperature factors $\left(\AA^{2}\right)$ for $\beta-\mathrm{Cu}_{0.50} \mathrm{TiO}\left(\mathrm{PO}_{4}\right)$ (first line for X-ray - second italic line for neutrons ; e.s.d. corrected with "Berar factor"[8])

\begin{tabular}{lllllll}
\hline Atom & Site & $\mathrm{x}$ & $\mathrm{y}$ & $\mathrm{z}$ & $\mathrm{B}_{\text {iso }}$ & Occ \\
\hline $\mathrm{Cu}$ & $2 \mathrm{a}$ & 0 & 0 & 0 & $0.9(2)$ & 1 \\
& & 0 & 0 & 0 & $0.79(17)$ & \\
$\mathrm{Ti}$ & $4 \mathrm{e}$ & $0.7363(9)$ & $0.2184(9)$ & $0.5353(9)$ & $0.6(2)$ & 1 \\
& & $0.731(7)$ & $0.217(6)$ & $0.531(7)$ & $0.4(2)$ & \\
$\mathrm{P}$ & $4 \mathrm{e}$ & $0.2485(17)$ & $0.1016(14)$ & $0.7497(18)$ & $0.4(2)$ & 1 \\
& & $0.240(7)$ & $0.105(3)$ & $0.744(6)$ & $0.48(15)$ & \\
$\mathrm{O}(1)$ & $4 \mathrm{e}$ & $0.759(3)$ & $0.148(3)$ & $0.770(3)$ & $0.2(2)$ & 1 \\
& & $0.770(7)$ & $0.153(3)$ & $0.770(5)$ & $0.70(7)$ & \\
$\mathrm{O}(2)$ & $4 \mathrm{e}$ & $0.814(3)$ & $0.024(2)$ & $0.121(2)$ & $0.2(2)$ & 1 \\
& & $0.812(5)$ & $0.023(4)$ & $0.117(4)$ & $0.70(7)$ & \\
$\mathrm{O}(3)$ & $4 \mathrm{e}$ & $0.440(3)$ & $0.214(3)$ & $0.896(3)$ & $0.2(2)$ & 1 \\
& & $0.447(4)$ & $0.206(3)$ & $0.904(4)$ & $0.70(7)$ & \\
$\mathrm{O}(4)$ & $4 \mathrm{e}$ & $0.310(3)$ & $-0.010(4)$ & $0.613(3)$ & $0.2(2)$ & 1 \\
& & $0.301(5)$ & $-0.012(4)$ & $0.612(4)$ & $0.70(7)$ & \multirow{2}{*}{$\mathrm{O}(5)$} \\
\multirow{2}{*}{$\mathrm{N})$} & $4 \mathrm{e}$ & $0.056(3)$ & $0.284(3)$ & $0.123(3)$ & $0.2(2)$ & 1 \\
& & $0.055(5)$ & $0.273(4)$ & $0.126(5)$ & $0.70(7)$ & \\
\hline
\end{tabular}


Table 3 : Bond distances $(\AA)$ and angles $\left(^{\circ}\right)$ for $\beta-\mathrm{Cu}_{0.5} \mathrm{TiO}\left(\mathrm{PO}_{4}\right): \mathrm{X}-\mathrm{O}(\mathrm{X}=\mathrm{Cu}, \mathrm{Ti}, \mathrm{P})$ distances are underlined; $\mathrm{O}-\mathrm{O}$ distances are given below the diagonal and $\mathrm{O}-\mathrm{X}-\mathrm{O}$ angles are given above.

(first lines for X-ray - second italic lines for neutrons ; e.s.d. corrected with "Berar factor"[8])

\begin{tabular}{|c|c|c|c|c|c|c|}
\hline $\mathrm{Ti}$ & $\mathrm{O}(1)$ & $\mathrm{O}(1)^{\mathrm{I}}$ & $\mathrm{O}(2)^{\mathrm{II}}$ & $\mathrm{O}(3)^{\mathrm{I}}$ & $\mathrm{O}(4)^{\mathrm{III}}$ & $\mathrm{O}(5)^{\mathrm{IV}}$ \\
\hline \multirow[t]{2}{*}{$\mathrm{O}(1)$} & $\underline{1.73(2)}$ & $167.9(1.9)$ & $96.8(1.8)$ & $99.2(1.7)$ & $102.0(1.8)$ & $97.7(1.8)$ \\
\hline & $1.70(5)$ & $163.2(3.5)$ & $95.2(3.0)$ & 101.3(3.3) & 104.1(3.3) & $94.2(3.8)$ \\
\hline \multirow[t]{2}{*}{$\mathrm{O}(1)^{\mathrm{I}}$} & $3.98(3)$ & $\underline{2.27(2)}$ & $72.8(1.3)$ & $86.7(1.5)$ & $87.9(1.7)$ & $74.8(1.3)$ \\
\hline & $3.95(4)$ & $2.29(5)$ & $72.5(2.4)$ & 89.3(3.2) & $86.4(2.8)$ & $72.1(2.8)$ \\
\hline \multirow[t]{2}{*}{$\mathrm{O}(2)^{\mathrm{II}}$} & $2.85(3)$ & $2.58(3)$ & $2.08(2)$ & $87.7(1.6)$ & $160.2(2.3)$ & $79.8(1.5)$ \\
\hline & $2.82(4)$ & $2.60(4)$ & $2.10(5)$ & $85.0(3.0)$ & 158.2(3.5) & 76.4(3.0) \\
\hline \multirow[t]{2}{*}{$\mathrm{O}(3)^{\mathrm{I}}$} & $2.78(3)$ & $2.88(3)$ & $2.77(3)$ & 1.91(2) & $95.3(1.9)$ & $159.9(2.0)$ \\
\hline & $2.76(4)$ & 2.93(5) & $2.68(4)$ & $1.86(6)$ & 100.8(3.4) & $156.8(4.2)$ \\
\hline \multirow[t]{2}{*}{$\mathrm{O}(4)^{\mathrm{III}}$} & $2.80(3)$ & $2.89(3)$ & $3.90(3)$ & $2.80(3)$ & $\underline{1.88(3)}$ & $91.6(1.7)$ \\
\hline & $2.80(4)$ & $2.85(4)$ & $3.87(4)$ & $2.86(4)$ & $1.85(5)$ & 91.9(3.3) \\
\hline \multirow{3}{*}{$\mathrm{O}(5)^{\mathrm{IV}}$} & $2.85(3)$ & $2.62(3)$ & $2.64(3)$ & $3.89(3)$ & $\overline{2.81(3)}$ & $2.04(2)$ \\
\hline & $2.77(6)$ & $2.57(4)$ & $2.57(5)$ & $3.84(5)$ & $2.81(5)$ & $2.06(7)$ \\
\hline & \multicolumn{6}{|c|}{$<$ Ti-O $>=1.99(1) 1.98(2) \AA$} \\
\hline $\mathrm{Cu}$ & $\mathrm{O}(1)^{\mathrm{V}}$ & $\mathrm{O}(1)^{\mathrm{III}}$ & $\mathrm{O}(2)^{\mathrm{VI}}$ & $\mathrm{O}(2)^{\mathrm{VII}}$ & $\mathrm{O}(5)$ & $\mathrm{O}(5)^{\mathrm{VIII}}$ \\
\hline \multirow[t]{2}{*}{$\mathrm{O}(1)^{\mathrm{V}}$} & $2.06(2)$ & 180.0 & $80.6(1.3)$ & $99.4(1.7)$ & $73.1(1.2)$ & $106.9(1.5)$ \\
\hline & $2.05(3)$ & 180.0 & $81.9(2.2)$ & $98.1(2.8)$ & $73.0(1.8)$ & $107.0(2.0)$ \\
\hline \multirow[t]{2}{*}{$\mathrm{O}(1)^{\mathrm{III}}$} & $\overline{4.12(4)}$ & $\underline{2.06(2)}$ & $99.4(1.7)$ & $80.6(1.3)$ & $106.9(1.5)$ & $73.1(1.2)$ \\
\hline & $4.10(6)$ & $2.05(3)$ & 98.1(2.8) & $81.9(2.2)$ & $107.0(2.0)$ & 73.0(1.8) \\
\hline \multirow[t]{2}{*}{$\mathrm{O}(2)^{\mathrm{VI}}$} & $2.58(3)$ & $\overline{3.04(3)}$ & $\underline{1.93(2)}$ & 180.0 & $76.0(1.4)$ & $104.0(1.6)$ \\
\hline & $2.60(4)$ & $3.00(5)$ & $\underline{1.92(3)}$ & 180.0 & $75.6(2.2)$ & $104.4(2.5)$ \\
\hline \multirow[t]{2}{*}{$\mathrm{O}(2)^{\mathrm{VII}}$} & $3.04(3)$ & $2.58(3)$ & $\overline{3.86(4)}$ & $\underline{1.93(2)}$ & $104.0(1.6)$ & $76.0(1.4)$ \\
\hline & $3.00(5)$ & $2.60(4)$ & $3.84(6)$ & $1.92(3)$ & $104.4(2.5)$ & $75.6(2.2)$ \\
\hline \multirow[t]{2}{*}{$\mathrm{O}(5)$} & $2.62(3)$ & $3.53(3)$ & $2.64(3)$ & $3.37(3)$ & $\underline{2.33(2)}$ & 180.0 \\
\hline & $2.57(4)$ & $3.46(4)$ & $2.57(5)$ & $3.30(5)$ & $2.26(3)$ & 180.0 \\
\hline \multirow[t]{3}{*}{$\mathrm{O}(5)^{\mathrm{VIII}}$} & I $3.53(3)$ & $2.62(3)$ & $3.37(3)$ & 2.64(3) & $\overline{4.66(4)}$ & $\underline{2.33(2)}$ \\
\hline & $3.46(4)$ & $2.57(4)$ & $3.30(5)$ & $2.57(5)$ & $4.52(6)$ & $\overline{2.26(3)}$ \\
\hline & \multicolumn{6}{|c|}{$<\mathrm{Cu}-\mathrm{O}>=2.11(1) 2.08(2) \AA$} \\
\hline \multicolumn{2}{|r|}{$\mathrm{P}$} & $\mathrm{O}(2)^{\mathrm{III}}$ & $\mathrm{O}(3)$ & $\mathrm{O}(4)$ & $\mathrm{O}(5)^{\mathrm{II}}$ & \\
\hline \multirow{2}{*}{\multicolumn{2}{|c|}{$\mathrm{O}(2)^{\mathrm{III}}$}} & $\underline{1.56(2)}$ & $110.7(2.4)$ & $107.3(2.3)$ & $107.2(2.2)$ & \\
\hline & & $\underline{1.58(5)}$ & 105.2(3.8) & 105.3(3.9) & $110.4(3.8)$ & \\
\hline \multirow{2}{*}{\multicolumn{2}{|c|}{$\mathrm{O}(3)$}} & $\overline{2.54(3)}$ & $\underline{1.52(2)}$ & $109.4(2.3)$ & $109.1(2.2)$ & \\
\hline & & $2.50(4)$ & $\underline{1.57(5)}$ & 107.8(3.6) & $110.8(4.1)$ & \\
\hline \multirow{2}{*}{\multicolumn{2}{|c|}{$\mathrm{O}(4)$}} & $2.50(3)$ & $\overline{2.50(3)}$ & $\underline{1.54(2)}$ & $113.1(2.6)$ & \\
\hline & & $2.48(5)$ & $2.51(4)$ & $\underline{1.54(5)}$ & $116.7(4.4)$ & \\
\hline \multirow{2}{*}{\multicolumn{2}{|c|}{$\mathrm{O}(5)^{\mathrm{II}}$}} & $2.47(3)$ & $2.47(3)$ & $\overline{2.54(3)}$ & $\underline{1.51(2)}$ & \\
\hline & & $2.53(4)$ & $2.52(5)$ & $2.58(5)$ & $\underline{1.50(5)}$ & \\
\hline
\end{tabular}

Symmetry codes :

(I) $\mathrm{x},-\mathrm{y}+1 / 2, \mathrm{z}-1 / 2$; (II) $\mathrm{x},-\mathrm{y}+1 / 2, \mathrm{z}+1 / 2$; (III) $-\mathrm{x}+1,-\mathrm{y},-\mathrm{z}+1$; (IV) $\mathrm{x}+1,-\mathrm{y}+1 / 2, \mathrm{z}+1 / 2$; (V) $\mathrm{x}-1, \mathrm{y}, \mathrm{z}-1$; (VI) $\mathrm{x}-1, \mathrm{y}, \mathrm{z} ;(\mathrm{VII})-\mathrm{x}+1,-\mathrm{y},-\mathrm{z} ;(\mathrm{VIII})-\mathrm{x},-\mathrm{y},-\mathrm{z}$; 
Table 4 : Bond valence calculation for $\beta-\mathrm{Cu}_{0.50} \mathrm{TiO}\left(\mathrm{PO}_{4}\right)$ with $\mathrm{X}$-ray results.

\begin{tabular}{llllll}
\hline & $\mathrm{Ti}$ & $\mathrm{P}$ & $\mathrm{Cu}$ & $\mathrm{S}_{\mathrm{i}}$ & $\sum_{\text {theo }}$ \\
\hline $\mathrm{O}(1)$ & 1.26 & & & & \\
$\mathrm{O}\left(1^{\prime}\right)$ & 0.29 & & & & \\
$\mathrm{O}(2)$ & 0.49 & 1.17 & $0.51(\times 2)$ & 2.17 & 2 \\
$\mathrm{O}(3)$ & 0.77 & 1.30 & & 2.07 & 2 \\
$\mathrm{O}(4)$ & 0.84 & 1.23 & & 2.07 & 2 \\
$\mathrm{O}(5)$ & 0.54 & 1.37 & $0.17(\times 2)$ & 2.08 & 2 \\
$\mathrm{~S}_{\mathrm{i}}$ & 4.19 & 5.07 & 2.08 & & \\
$\sum_{\text {theo }}$ & 4 & 5 & 2 & & \\
\hline
\end{tabular}

Table 5 : Cell parameters evolution in $M_{0,5} \mathrm{TiOPO}_{4}$ compounds, according to $M$ size.

\begin{tabular}{ccccccc} 
Oxyphosphate & $\mathrm{r}_{\mathrm{M} 2+}(\AA)$ & $\mathrm{a}(\AA)$ & $\mathrm{b}(\AA)$ & $\mathrm{c}(\AA)$ & $\beta\left(^{\circ}\right)$ & $\mathrm{V}\left(\AA^{3}\right)$ \\
\hline $\boldsymbol{\alpha}-\mathbf{C u}_{\mathbf{0}} \mathbf{T i O P O}_{4}$ & $\mathbf{0 . 7 3 0}$ & $\mathbf{7 . 5 6 1 ( 1 )}$ & $\mathbf{7 . 0 9 2 ( 1 )}$ & $\mathbf{7 . 4 8 7 ( 1 )}$ & $\mathbf{1 2 2 . 2 5 ( 1 )}$ & $\mathbf{3 3 9 . 5 ( 1 )}$ \\
$\mathrm{Fe}_{0.5} \mathrm{TiOPO}_{4}$ & $0.780(\mathrm{HS})$ & $7.404(1)$ & $7.384(1)$ & $7.408(1)$ & $120.36(2)$ & $349.5(1)$ \\
$\mathrm{Co}_{0.5} \mathrm{TiOPO}_{4}$ & $0.745(\mathrm{HS})$ & $7.388(1)$ & $7.367(1)$ & $7.375(1)$ & $120.34(2)$ & $346.4(1)$ \\
$\mathrm{Zn}_{0.5} \mathrm{TiOPO}_{4}$ & 0.740 & $7.388(1)$ & $7.380(1)$ & $7.373(1)$ & $120.34(2)$ & $346.9(1)$ \\
$\mathrm{Mg}_{0.5} \mathrm{TiOPO}_{4}$ & 0.720 & $7.367(1)$ & $7.385(1)$ & $7.374(1)$ & $120.23(2)$ & $346.6(1)$ \\
$\mathrm{Ni}_{0.5} \mathrm{TiOPO}_{4}$ & 0.690 & $7.383(1)$ & $7.323(1)$ & $7.344(1)$ & $120.23(1)$ & $343.1(1)$ \\
$\boldsymbol{\beta}-\mathbf{C u}_{\mathbf{0 . 5}} \mathbf{T i O P O}_{4}$ & $\mathbf{0 . 7 3 0}$ & $\mathbf{7 . 1 1 3 ( 1 )}$ & $\mathbf{7 . 7 2 8 ( 1 )}$ & $\mathbf{7 . 3 0 3 ( 1 )}$ & $\mathbf{1 1 9 . 3 0 ( 1 )}$ & $\mathbf{3 5 0 . 1 ( 1 )}$ \\
\hline
\end{tabular}




\section{FIGURES CAPTIONS}

Fig1 Evolution of X-ray patterns during thermal cycle :

a) for $\alpha_{100}$-powder

b) for $\left(\alpha_{20}+\beta_{80}\right)$-powder

Fig2 Final Rietveld plots of $\beta-\mathrm{Cu}_{0.50} \mathrm{TiO}\left(\mathrm{PO}_{4}\right)$ for $\mathrm{X}$-ray and neutrons data. The upper trace illustrates the observed data (dots) and the calculated pattern (solid line). The vertical markers show positions calculated for Bragg reflections. The lower trace is the difference function between observed and calculated values.

Fig3 Three dimensional view of $\beta-\mathrm{Cu}_{0.50} \mathrm{TiO}\left(\mathrm{PO}_{4}\right)$ framework.

Fig4 $\alpha \rightarrow \beta$ transition in $\mathrm{Cu}_{0.50} \mathrm{TiO}\left(\mathrm{PO}_{4}\right)$ illustrated by the rocking of Jahn Teller effect in $\mathrm{Cu}$ octahedral environment.

Fig5 Powders evolutions with temperature :

a) $\alpha$-phase weight fraction variation during a thermal cycle with $\alpha_{100}$-powder

b) $\alpha$-phase weight fraction variation during a thermal cycle with $\left(\alpha_{20}+\beta_{80}\right)$-powder

c) cells volumes dilatations with increasing temperature for $\alpha$ and $\beta$ phases.

Fig6 Thermal study of $\alpha_{100}$-powder :

a) calorimetry

b) dilatometry

Fig7 Graphical abstract. 


$$
-19-
$$



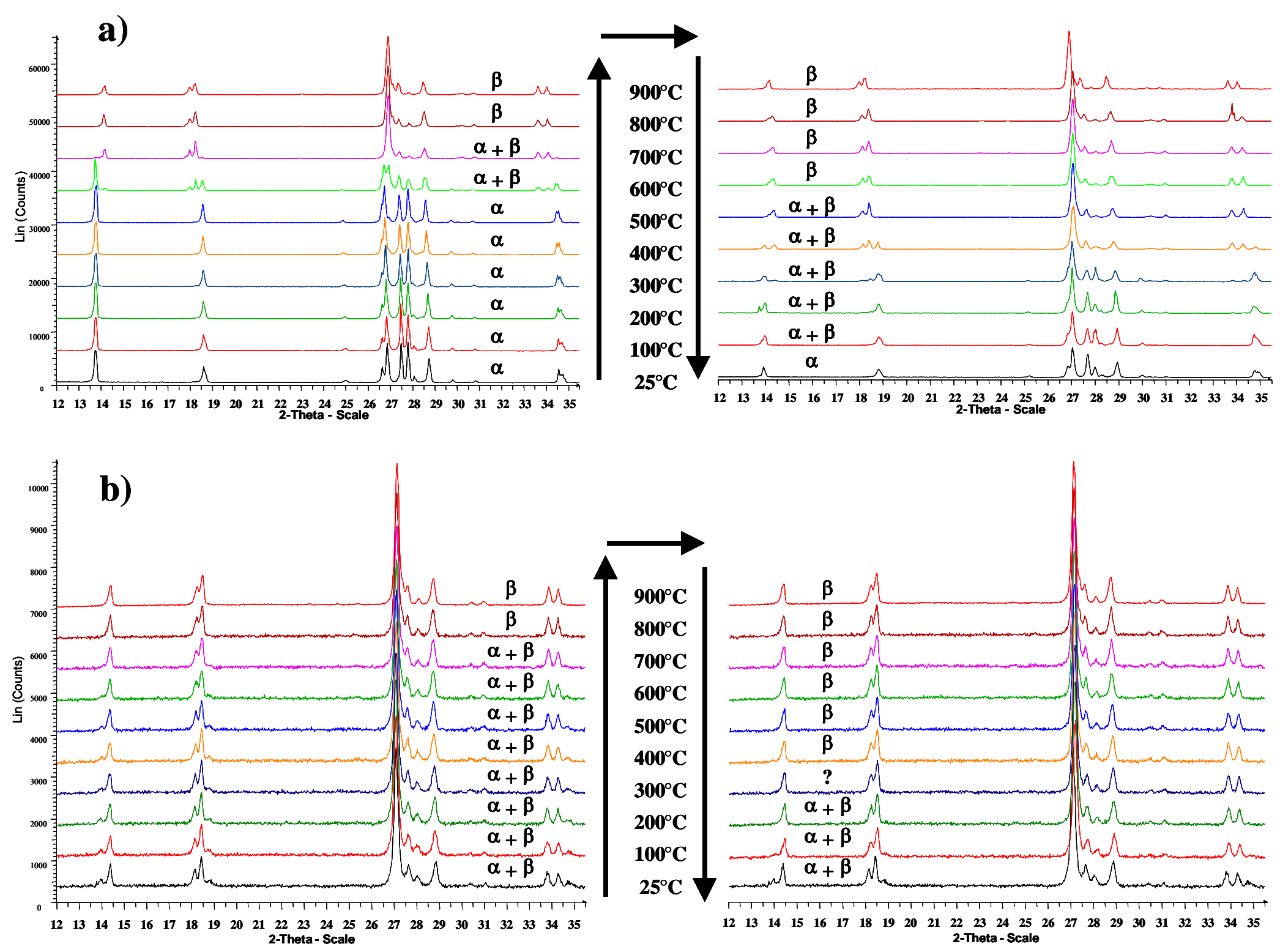

Fig. 1 

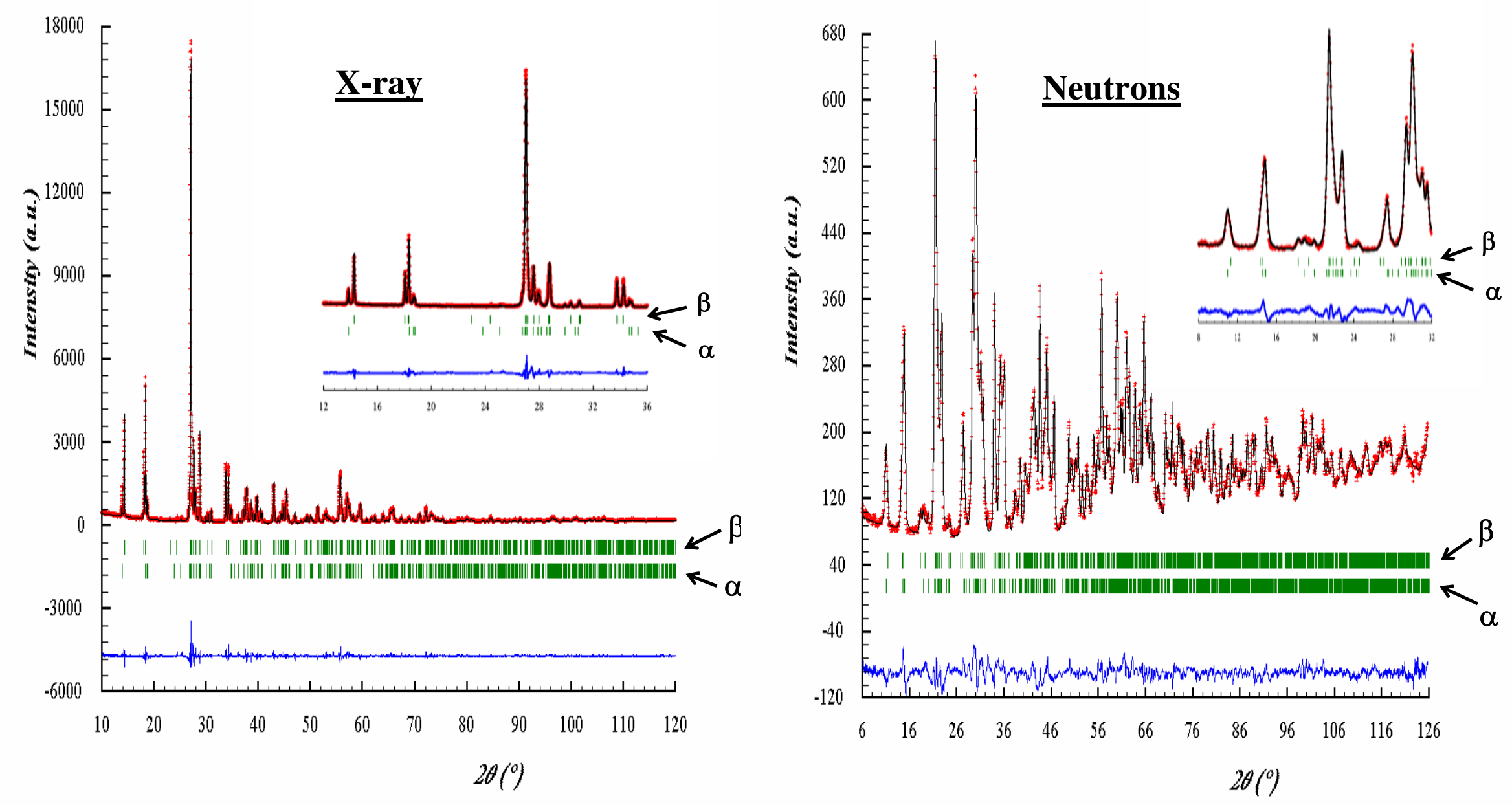

Fig. 2 


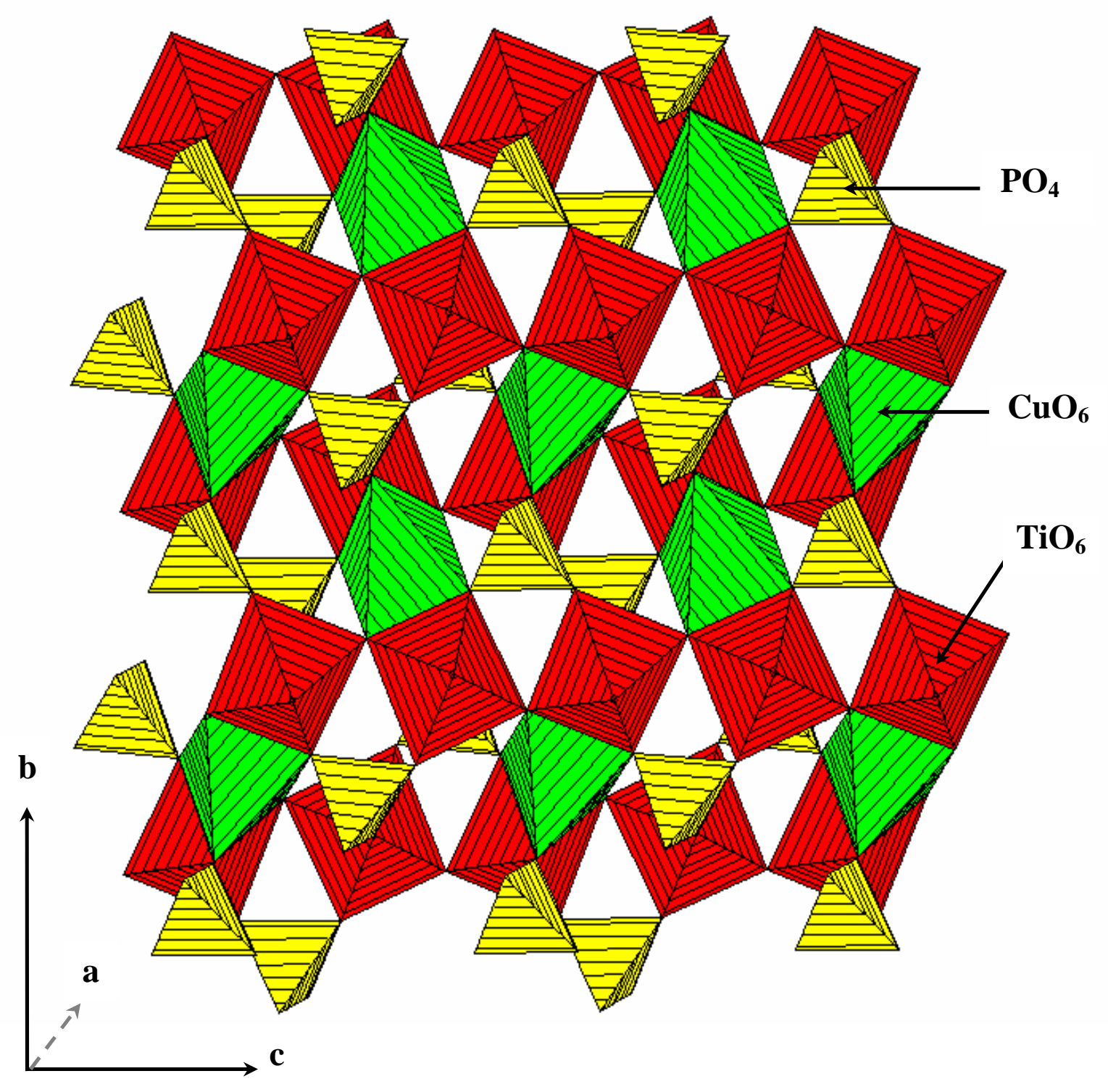

Fig. 3 

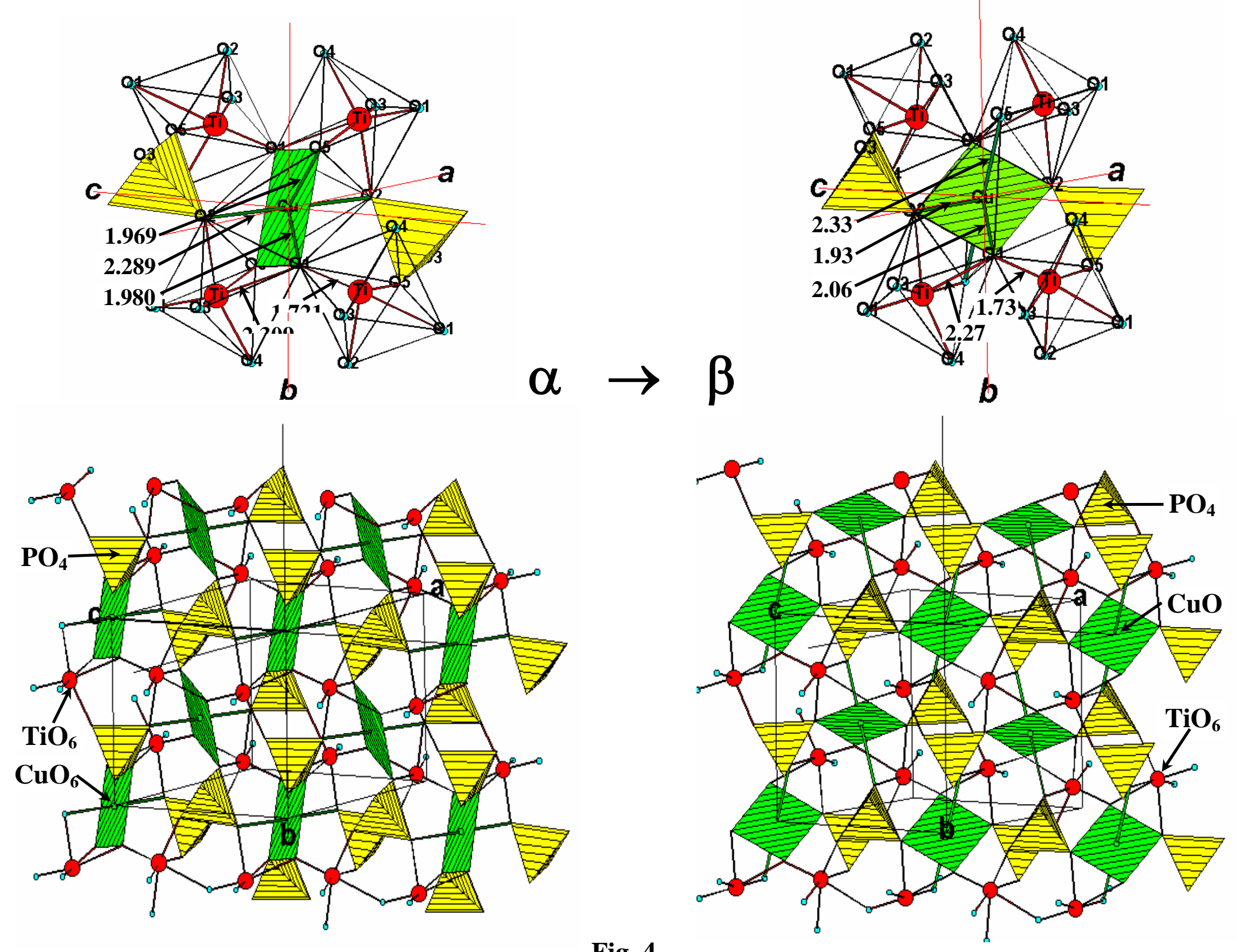

Fig. 4 


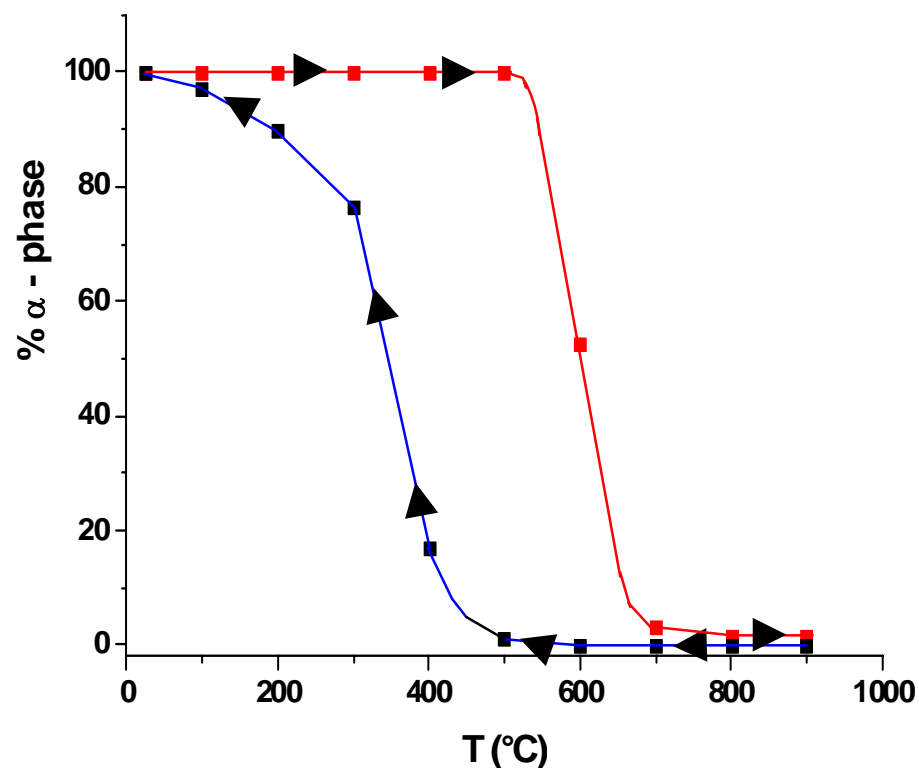

a)

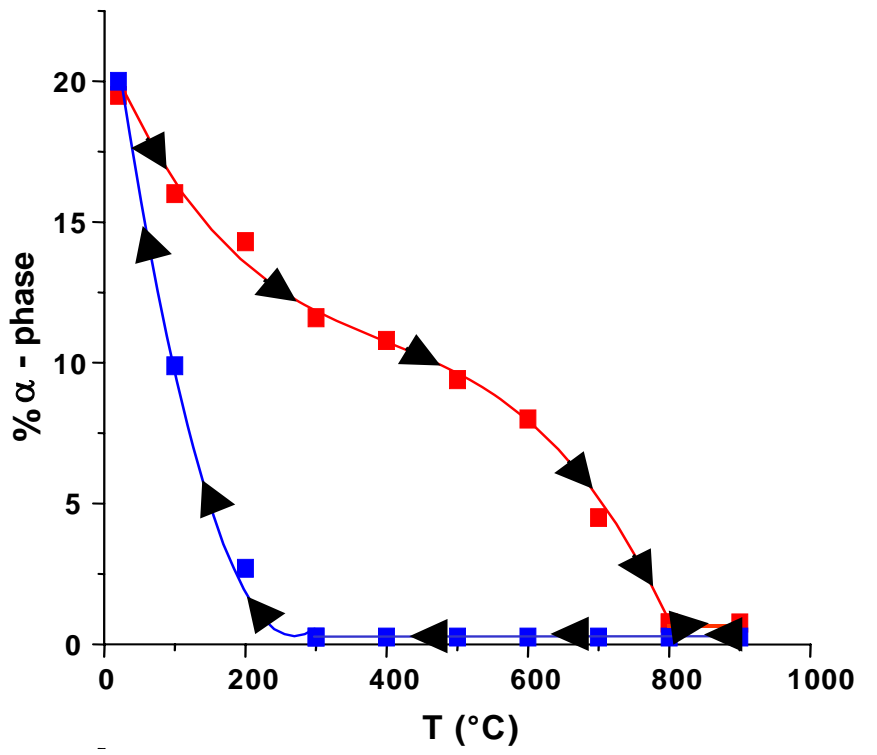

b)

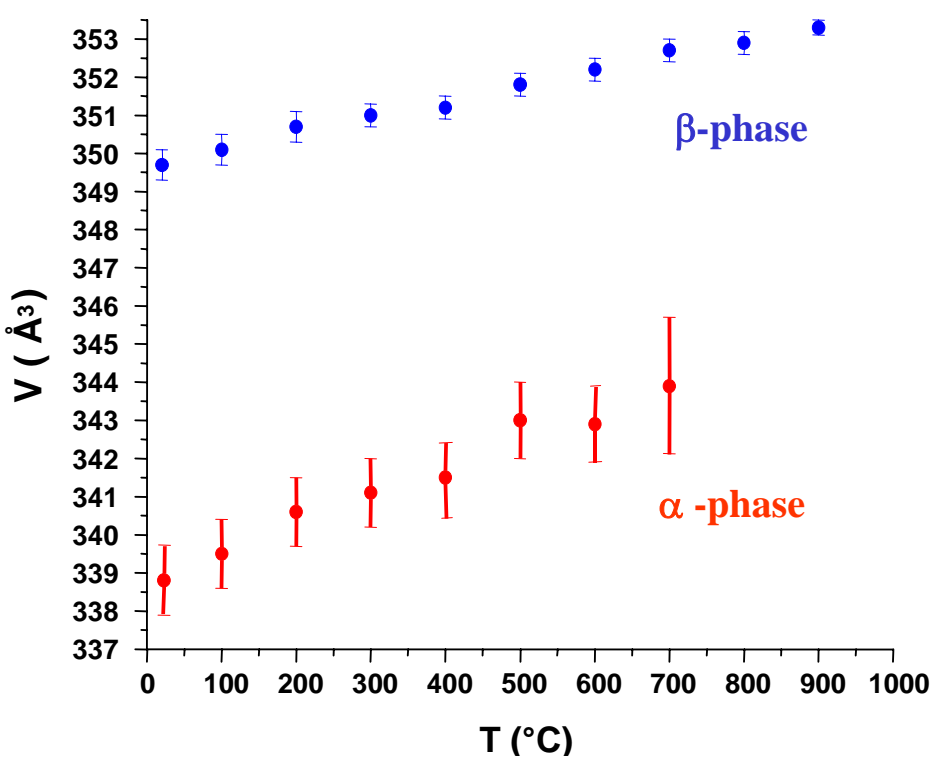

c)

Fig. 5 


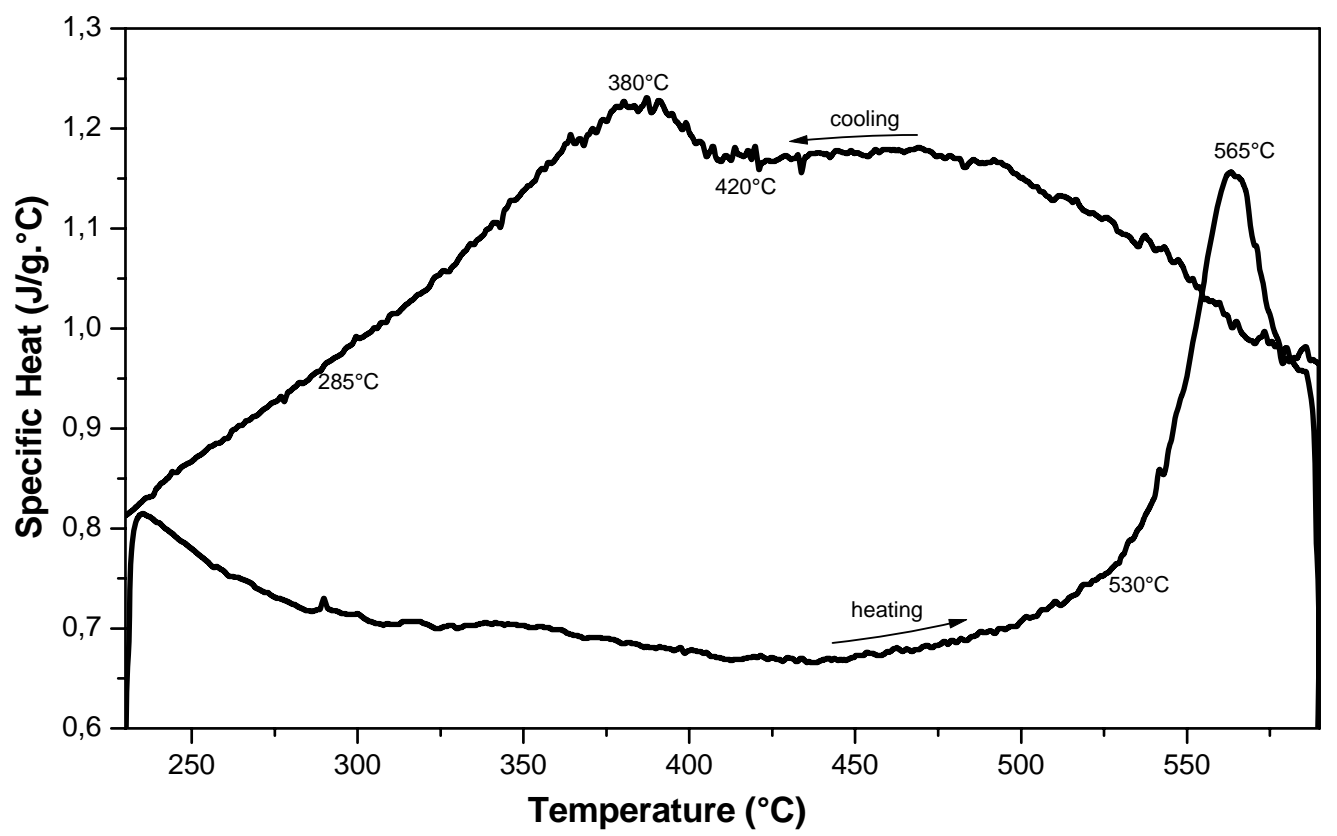

6a : calorimetry

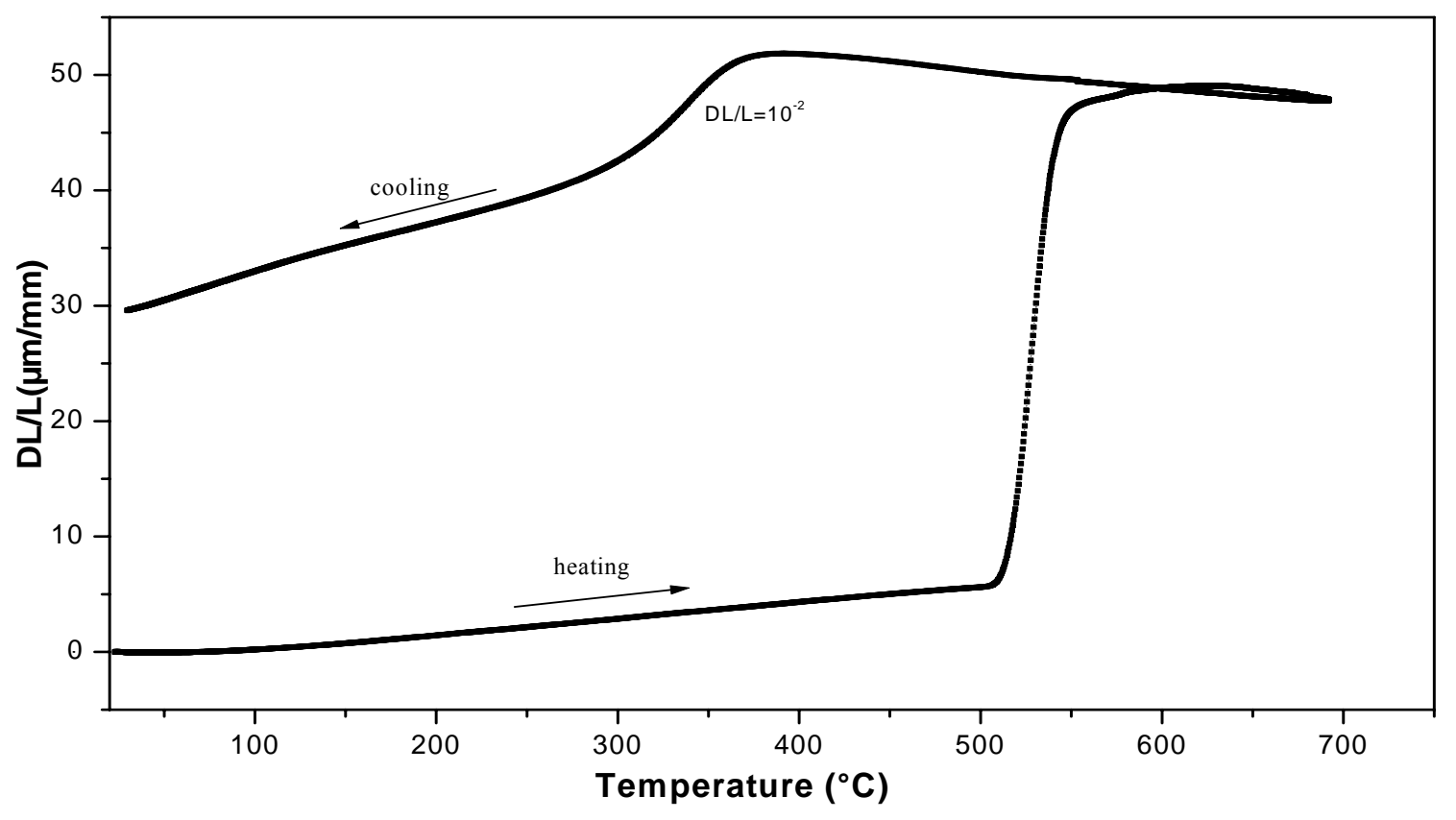

$6 \mathrm{~b}$ : dilatometry

Fig. 6 

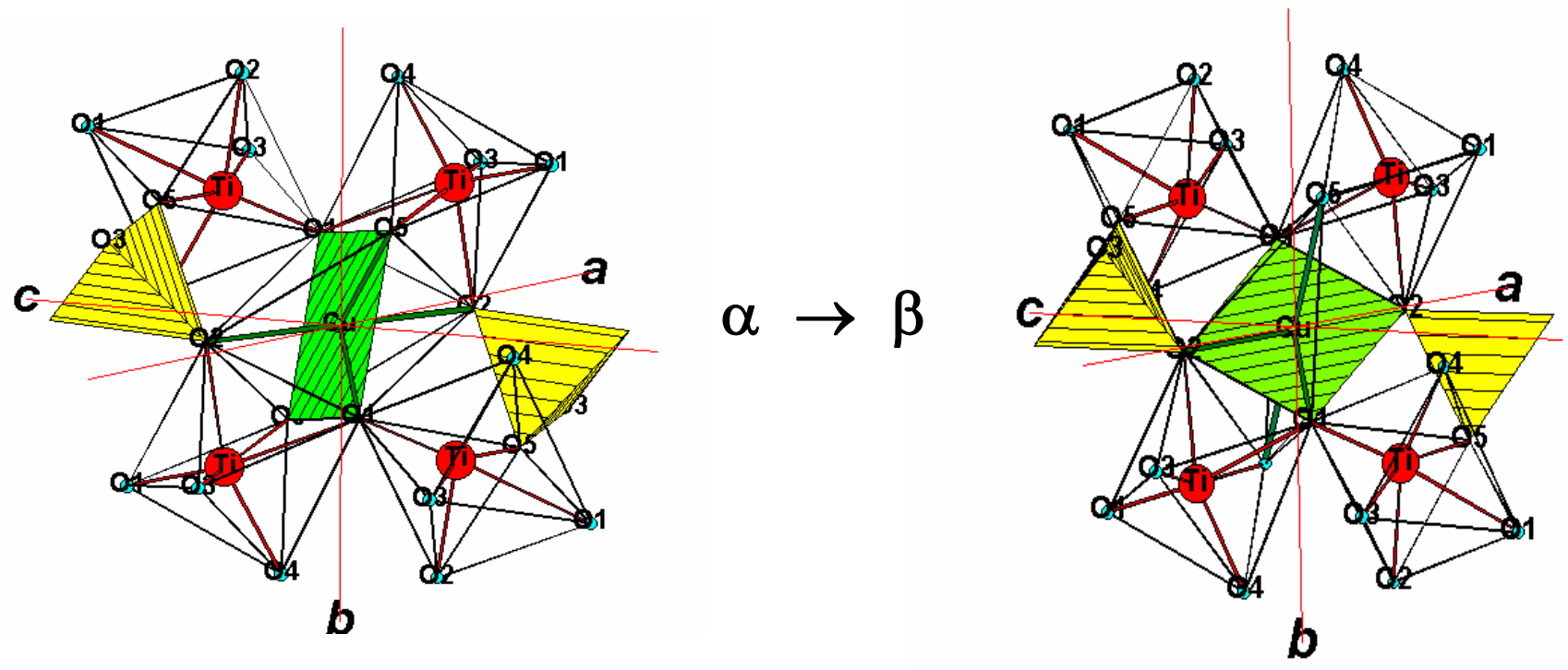

Fig. 7 